\title{
Fruits Contaminated with Lead, Cadmium and Nitrate are the Risks to Human
}

\section{Health: A seasonal study}

\section{Reza Sharafati Chaleshtori*1(i), Zahra Jadi 2 (i)}

${ }^{1} \mathrm{PhD}$ of Food Hygiene, Research Center for Biochemistry and Nutrition in Metabolic Diseases, Kashan University of Medical Sciences, Kashan, Iran. ${ }^{2}$ Department of Food and drink monitoring, Kashan University of Medical Sciences, Kashan, Iran.

\begin{tabular}{l}
\hline Article Info \\
\hline Article Type: \\
Research \\
\hline Article History: \\
Received: 01.08.2019 \\
Accepted: 08.10.2019 \\
\\
*Corresponding Author: \\
Reza Sharafati Chaleshtori \\
PhD of Food Hygiene, Research \\
Center for Biochemistry and \\
Nutrition in Metabolic Diseases, \\
Kashan University of Medical \\
Sciences, Kashan, Iran. \\
E-mail: sharafati.reza@gmail.com
\end{tabular}

A B S T R A C T

Background:

Consumers may be contaminated by various food intakes as one of the most important sources of organic and inorganic pollutants associated with agriculture. The aim of this study was to evaluate the lead (Pb), cadmium (Cd) and nitrate contaminations in watermelon and carrot samples and the associated risks to human health.

\section{Methods:}

In this cross sectional study, 108 samples of watermelon and carrot samples were collected randomly from the supermarkets in Kashan, Iran, from October 2017 to September 2018. Inductively coupled plasma optical emission spectroscopy (ICP-OES) and spectrophotometry were used to analyze $\mathrm{Pb}, \mathrm{Cd}$ and nitrate in the collected samples, respectively.

\section{Results:}

The results showed that the carrot samples had the most concentrations of $\mathrm{Pb}, \mathrm{Cd}$ and nitrate than those for watermelon $(\mathrm{p}<0.001)$. All of the samples except for some watermelons and carrots had lower contaminants than the permissible standard limits. The results of the target hazard quotient (THQ) and total THQ for the compounds were within the safe range $(<1)$ and were not detected at harmful levels. The excess lifetime cancer risk (ELCR) of $\mathrm{Pb}$ and $\mathrm{Cd}$ were in the safe and unsafe range, respectively. However, the total cancer risk was higher than the standard level and was; therefore, unsafe to the consumers.

Conclusion:

The study showed that the concentrations of the compounds in carrot and watermelon may potentially be hazardous to the health of Iranian consumers.

Keywords:

Cadmium, Health Risk, Lead, Nitrates, Seasons

How to cite this paper:

Sharafati Chaleshtori R, Jadi Z. Fruits Contaminated with Lead, Cadmium and Nitrate are the Risks to Human Health: A seasonal study. Iran J Toxicol. 2019;13(4): 27-32

\section{INTRODUCTION}

The consumption of fruits, such as watermelons and carrots have increased since people have become aware that fruits contain beneficial anti-oxidants, and are the main sources of vitamins, carbohydrates, minerals and fibers ( 1 ). Consumers can be contaminated by food intakes as one of the most important sources of organic and inorganic pollutants associated with agricultural products.

Heavy metals such as lead $(\mathrm{Pb})$ and cadmium (Cd) with the atomic mass of $>5 \mathrm{~g} / \mathrm{cm}^{3}$, are among the popular pollutants that are not biodegradable and may accumulate in fruits and vegetables (2). These heavy metals are known to have numerous adverse effects on humans and are ranked the second $(\mathrm{Pb})$ and seventh (Cd), respectively, on the priority list of dangerous compounds published by the US Environmental Protection Agency (USEPA) ( $\underline{3}$ ). Both $\mathrm{Pb}$ and $\mathrm{Cd}$ have a long half-life in human tissues and can cause adverse effects on the normal functions of nerves, kidneys, lungs and liver $(\underline{3,4})$. The main sources of $\mathrm{Pb}$ and $\mathrm{Cd}$ contaminations are industrial products and agricultural chemicals, such as superphosphate fertilizers (ㅍ). Alimohammadi et al. (1) demonstrated that the order of metal contaminations in the tested fruits and vegetables collected from Tehran markets was:

$\mathrm{Zn}>\mathrm{Cr}>\mathrm{Ni}>\mathrm{Cu}>\mathrm{Pb}>\mathrm{Cd}>$ As. Also, the mean concentrations of $\mathrm{Pb}$ and $\mathrm{Cr}$ for cabbage, potatoes and carrots were higher than the permissible limits in the summer (1). A previous study has reported that the levels of $\mathrm{Pb}$ and $\mathrm{Cd}$ in vegetables were more than the maximum levels permitted for foods in China (므). 
In recent years, the hazards posed by nitrate and nitrite in various foods have given rise to multiple debates in the scientific community. Previous studies have shown that high dietary intakes of nitrate and nitrite are implicated in the etiology of some human cancers. However, some researchers have suggested beneficial effects for nitrate and nitrite, such as lowering hypertension and cardiovascular diseases (6-8). The hazards of nitrate are due to its nitrosamines and nitrosyl-heme forms which are known to be mutagenic $(\underline{7,9})$. Bahadoran et al. reported that vegetables collected from some Tehran's supermarkets with the highest nitrate concentrations, including radish, beetroot, tarragon, lettuce, mint, and celery ( $\underline{10})$. Also, Brkić et al. showed that there were significant differences in nitrate levels among the leafy green vegetables analyzed. They concluded that the nitrate levels were not a serious concern toward public health (11).

Considering the high public concern regarding the dietary intakes of heavy metals and nitrate from various foods, the aim of this study was to assess the concentrations of $\mathrm{Pb}, \mathrm{Cd}$ and nitrate in watermelon and carrot samples in a mid-sized Iranian city (Kashan) and to estimate their associated risks to human health.

\section{MATERIALS AND METHODS}

Sample Collection and Preparation: This crosssectional study was carried out from October 2017 to September 2018. A total of 108 watermelon $(n=48)$ and carrot $(n=60)$ samples were collected randomly at supermarkets and retail stores at six locations in Kashan, Iran. Sampling locations were identified with the largest stock of and the customer demands for watermelons and carrots. At each season, a total of 27 samples were collected (12 watermelon \& 15 carrot samples), with the weight of each sample being at least one $\mathrm{kg}$. All samples were transferred immediately to the laboratory in plastic bags for further analysis. Initially, samples were washed and dried at room temperature in the lab. After removing the damaged parts, the fruits were homogenized within 24 hours.

\section{Analytical Methods}

Measurement of Nitrate: Nitrate concentrations in samples were determined using the standards of the association of analytical communities (AOAC) and Institute of Standards and Industrial Research of Iran (ISIRI) $(\underline{12,13})$. For the preparation of samples, $0.5 \mathrm{~g}$ of each sample was oven dried at $70^{\circ} \mathrm{C}$ and was added to 50mL 2\% acetic acid (Merck Co., Darmstadt, Germany), shaken for $30 \mathrm{~min}$ and filtered. $5 \mathrm{~mL}$ ammonium chloride buffered solution $(\mathrm{pH}=9.6)$ and $2 \mathrm{~g}$ reduced cadmium were added to $10 \mathrm{~mL}$ of the above solution and adjusted to $50 \mathrm{~mL}$ with distilled water. Then, $5 \mathrm{~mL}$ disodium tetraborate solution $(50 \mathrm{~g} / 1000 \mathrm{~mL})$ and $100 \mathrm{~mL}$ hot distilled water $\left(80^{\circ} \mathrm{C}\right)$ were mixed with the above solution. After boiling, $2 \mathrm{~mL}$ potassium hexacyanoferrate solution $(106 \mathrm{~g} / 1000 \mathrm{~mL})$ and $2 \mathrm{~mL}$ zinc acetate solution $(220 \mathrm{~g} / 1000 \mathrm{~mL})$ were added and the volume was adjusted to $200 \mathrm{~mL}$ with distilled water and filtered. Ten milliliters of this solution were used instead of the standard solution for the next steps of the experiment.
A calibration curve was prepared as follows: 0, 0.5, 1, 2, and $3 \mathrm{~mL}$ sodium nitrite $(15 \mu \mathrm{g} / \mathrm{mL})$ solution (Merck Co., Darmstadt, Germany) were added to 30, 29.5, 29, 28 and $27 \mathrm{~mL}$ distilled water, respectively, as standard solutions. Then, $5 \mathrm{~mL}$ sulfanilamide reagent $0.4 \mathrm{~g}$ sulfanilamide in $160 \mathrm{~mL}$ distilled water containing $20 \mathrm{~mL}$ of $\mathrm{HCl}$ were adjusted to $200 \mathrm{~mL}$ with distilled water) and $3 \mathrm{~mL}$ of $\mathrm{HCl}$ solution $(4.45 \mathrm{~mL} / 10 \mathrm{~mL})$ was added, mixed and stored in darkness for five min. One milliliter $\mathrm{N}$-(1-Naphthyl) ethylenediamine solution $(0.1 \mathrm{~g} / 1000 \mathrm{~mL})$ was added to the above mixture and stored in darkness for three min. Finally, this solution was adjusted to $50 \mathrm{~mL}$ with distilled water. The absorbance was measured on a spectrophotometer (CECIL 2021, England) at 538nm. The calibration curve was constructed with correlation factors 0.996 with the recovery rate being $98 \%$. The nitrate concentration in the sample was reported as $\mathrm{mg} \mathrm{NO}_{2} / \mathrm{kg}$. Distilled water was used as the negative control while the sodium nitrite solution was the positive control. All of the chemicals were in analytical grades.

Determination of $\mathrm{Pb}$ and $\mathrm{Cd}$ Concentrations: In order to determine the $\mathrm{Pb}$ and $\mathrm{Cd}$ concentrations, the samples were prepared as follows: ground samples were oven dried for $24 \mathrm{~h}$ at $105^{\circ} \mathrm{C}$ and $500 \mathrm{mg}$ of each sample was weighted and digested with $10 \mathrm{~mL}$ concentrated (65\%) nitric acid (Merck Co, Darmstadt, Germany) on a hot plate. This solution was filtered through Whatman filter paper No. 42, and the filtrate from each sample was adjusted to $25 \mathrm{ml}$, using deionized water.

The $\mathrm{Pb}$ and $\mathrm{Cd}$ concentrations were determined by inductively coupled plasma optical emission spectroscopy (ICP-OES, PerkinElmer: Optima 2100 DV). The standard solutions of $\mathrm{Pb}$ and $\mathrm{Cd}$ were prepared by diluting stock solutions at $100 \mathrm{mg} / \mathrm{mL}$ of the stock standard solutions, using $1 \%(\mathrm{w} / \mathrm{w})$ nitric acid. The detection limit and recovery rate for $\mathrm{Pb}$ and $\mathrm{Cd}$ were 2.2 to $4.1 \mathrm{ng} / \mathrm{L}(94 \%$ vs $97 \%)$, respectively. The concentrations of $\mathrm{Pb}$ and $\mathrm{Cd}$ were reported in $\mu \mathrm{g} / \mathrm{kg}$ of the dry weight in the samples (14).

\section{Health Risk Assessment for $\mathrm{Pb}, \mathrm{Cd}$ and Nitrate:} The average daily consumption among the Iranian population for watermelons and carrots were 109 $\mathrm{g} /$ day and $39 \mathrm{~g} /$ day, respectively $(\underline{14})$. The average daily doses (ADD) for $\mathrm{Pb}, \mathrm{Cd}$, and nitrate were calculated by the mean concentrations of the compounds for each fruit sample. In the worst case scenario, the maximum concentration for each compound was identified $(\underline{1,15})$ based on the following equation: $\boldsymbol{A D D}=\boldsymbol{C} \times \boldsymbol{I R} \times \boldsymbol{E F} \times \boldsymbol{E D} / \boldsymbol{B} \boldsymbol{W} \times \boldsymbol{A T}$ where, $\boldsymbol{A D D}$ is average daily dose ( $\mathrm{mg} / \mathrm{kg}$ body weight/day), $\boldsymbol{C}$ is the mean compound concentrations $(\mathrm{mg} / \mathrm{kg}), \boldsymbol{I R}$ is the mean food consumption (kg/day), $\boldsymbol{E F}$ is exposure frequency (350 days/year), $\boldsymbol{E D}$ is the exposure duration (70 years), $\boldsymbol{B} \boldsymbol{W}$ is the average body weight set to $70 \mathrm{~kg}$ in this study, $\boldsymbol{A T}$ is the averaging time (365 days/year $\times$ the years of exposure, i.e., 70 years). For the evaluation of non-carcinogenic risk, the target hazard quotient (THQ) was calculated, using the following equations: $\boldsymbol{T H Q}=\boldsymbol{A D D} / \boldsymbol{R} \boldsymbol{D}$ where, $\boldsymbol{T H Q}$ was target hazard quotient, $\boldsymbol{A D D}$ was average daily dose $(\mathrm{mg} / \mathrm{kg}$ bw/day), $\boldsymbol{R} \boldsymbol{f D}$ was the reference dose $(\mathrm{mg} / \mathrm{kg}$ 
bw/day). The $R f D$ values for $\mathrm{Pb}, \mathrm{Cd}$, and nitrate were $0.00035,0.001$ and 1.6 , respectively $(\underline{1,16})$. The THQ values more than 1 (THQ>1) reflected a significant risk level, indicating a greater likelihood of harmful noncarcinogenic health impact (15). The total target hazard quotients (TTHQ) from the consumption of $\mathrm{Pb}$, $\mathrm{Cd}$ and nitrate for watermelons and carrots were calculated as the sum of THQs for the fruit samples and expressed as follows: $\boldsymbol{T T H Q}=\boldsymbol{T H} \boldsymbol{Q}_{1}+\boldsymbol{T H} \boldsymbol{Q}_{2}+\ldots+$ $\mathrm{THQ}_{n}$.

Carcinogenic Risk Assessment for Pb And Cd: In order to measure the carcinogenic risks for $\mathrm{Pb}$ and $\mathrm{Cd}$, the lifetime average daily dose (LADD) and the excess lifetime cancer risk (ELCR) were calculated using the following equations: $L A D D=C \times I R \times E F \times E D / B W \times A T$ and
$\boldsymbol{E L C R}=\boldsymbol{L A D D} \times \boldsymbol{C S F}$, where $\boldsymbol{L A D D}$ was the lifetime average daily dose (mg/kg-day), and other factors remained the same as for $A D D$ equation. Also, $\boldsymbol{C S F}$ represented the cancer slope factor; and the $C S F$ values of $\mathrm{Pb}$ and $\mathrm{Cd}$ were 0.0085 and 6.3 , respectively ( 1 ). The acceptable range of risk levels for carcinogens was $10^{-4}$ to $10^{-6}$.

Statistical Analysis: The study data were statistically analyzed, using SPSS version 18.0 (SPSS Inc., Chicago, IL, USA) and the results were presented in Tables 1-4. The final data were the mean \pm standard deviation (SD) for each sample, which were analyzed by chi-squared, $t$-test and one-way analysis of variance (ANOVA), with the minimum significance level being $\mathrm{P}<0.05$.

Table 1. Lead, cadmium and nitrate contents in watermelons and carrots

\begin{tabular}{|c|c|c|c|c|c|c|}
\hline Compound & Fruit & $\begin{array}{c}\text { Mean } \pm \text { SD } \\
(\mu \mathrm{g} / \mathrm{kg})\end{array}$ & $\begin{array}{c}\text { Min } \\
(\mu \mathrm{g} / \mathrm{kg})\end{array}$ & $\begin{array}{c}\text { Max } \\
(\mu \mathrm{g} / \mathrm{kg})\end{array}$ & $\begin{array}{c}\text { PL } \\
(\mu \mathrm{g} / \mathrm{kg})\end{array}$ & $\begin{array}{c}\text { Samples \# } \\
(\mathrm{PL})\end{array}$ \\
\hline \multirow[t]{2}{*}{ Lead } & Watermelon & $18.68 \pm 16.1^{\mathrm{A}}$ & $\mathrm{ND}^{2}$ & 74.43 & 100 & $0(0 \%)$ \\
\hline & Carrots & $30.83 \pm 15.88^{B}$ & 0.81 & 76.88 & & $0(0 \%)$ \\
\hline \multirow[t]{2}{*}{ Cadmium } & Watermelon & $2.40 \pm 2.72^{\mathrm{A}}$ & ND & 13.40 & 50 & $0(0 \%)$ \\
\hline & Carrots & $5.25 \pm 3.47^{\text {в }}$ & 1.75 & 26.20 & & $0(0 \%)$ \\
\hline \multirow[t]{2}{*}{ Nitrate $^{3}$} & Watermelon & $46300 \pm 35880^{A}$ & 0.00 & 181170 & 60000 & $12(25 \%)$ \\
\hline & Carrots & $183230 \pm 181260^{\text {В }}$ & 8630 & 599590 & 250000 & $18(30 \%)$ \\
\hline
\end{tabular}

1. PL: Permissible level of Institute of Standard and Industrial Research of Iran $(\mu \mathrm{g} / \mathrm{kg})$.

2. ND: Not detected (<LOD). 3. Nitrate was determined by spectrophotometry.

Table 2. Seasonal cumulative lead, cadmium and nitrate contents in watermelons and carrots.

\begin{tabular}{clllll}
\hline Compound & Season & \multicolumn{1}{c}{$\begin{array}{c}\text { Mean } \mathbf{S D} \\
(\boldsymbol{\mu g} / \mathbf{k g})\end{array}$} & $\begin{array}{c}\text { Min } \\
(\boldsymbol{\mu g} / \mathbf{k g})\end{array}$ & $\begin{array}{c}\text { Max } \\
(\boldsymbol{\mu g} / \mathbf{k g})\end{array}$ & $\begin{array}{c}\text { Sample \# } \\
\boldsymbol{> ~ P L}^{\mathbf{1}}\end{array}$ \\
\hline Lead & Spring & $29.66 \pm 15.87^{\mathrm{A}}$ & 1.18 & 76.88 & $0(0 \%)$ \\
& Summer & $26.98 \pm 11.51^{\mathrm{A}}$ & $\mathrm{ND}^{2}$ & 57 & $0(0 \%)$ \\
& Autumn & $17.43 \pm 21.4^{\mathrm{B}}$ & 0.81 & 73.82 & $0(0 \%)$ \\
& Winter & $27.66 \pm 15.98^{\mathrm{A}}$ & $\mathrm{ND}$ & 74.43 & $0(0 \%)$ \\
Cadmium & Spring & $3.2 \pm 2.1^{\mathrm{A}}$ & $\mathrm{ND}$ & 7.11 & $0(0 \%)$ \\
& Summer & $3.03 \pm 2.18^{\mathrm{AC}}$ & 0.53 & 7.30 & $0(0 \%)$ \\
& Autumn & $4.77 \pm 5^{\mathrm{A}}$ & 0.7 & 26.20 & $0(0 \%)$ \\
& Winter & $4.95 \pm 3.42^{\mathrm{AB}}$ & 0.69 & 13.40 & $0(0 \%)$ \\
& Spring & $38550 \pm 27650^{\mathrm{A}}$ & 8630 & 117950 & $3(2.7 \%)$ \\
& Summer & $137970 \pm 191980^{\mathrm{B}}$ & 0.00 & 599590 & $5(4.62 \%)$ \\
& Autumn & $183620 \pm 160580^{\mathrm{B}}$ & 8.43 & 580340 & $12(11.11 \%)$ \\
& Winter & $129350 \pm 145650^{\mathrm{B}}$ & 0.00 & 510080 & $10(9.26 \%)$ \\
\hline
\end{tabular}

1. PL: Permissible level of Institute of Standard and Industrial Research of Iran $(\mu \mathrm{g} / \mathrm{kg})$

2. ND: Not detected (<LOD).

Table 3. The seasonal concentrations of lead, cadmium and nitrate in watermelons and carrots.

\begin{tabular}{|c|c|c|c|c|c|c|c|}
\hline Compound & Seasons & Fruit & $\begin{array}{c}\text { Mean } \pm \text { SD } \\
(\mu \mathrm{g} / \mathrm{kg})\end{array}$ & $P$ value & $\begin{array}{c}\text { Min } \\
(\mu \mathrm{g} / \mathrm{kg})\end{array}$ & $\begin{array}{c}\text { Max } \\
(\mu \mathrm{g} / \mathrm{kg})\end{array}$ & $\begin{array}{c}\text { Sample \# } \\
(\mathrm{PL})\end{array}$ \\
\hline \multirow[t]{8}{*}{ Lead } & \multirow[t]{2}{*}{ Spring } & Watermelon & $16.17 \pm 7.59$ & \multirow[t]{2}{*}{$\mathrm{P}=0.000$} & 1.18 & 26.78 & $0(0 \%)$ \\
\hline & & Carrot & $40.44 \pm 11.9$ & & 25.62 & 76.88 & $0(0 \%)$ \\
\hline & \multirow[t]{2}{*}{ Summer } & Watermelon & $19.28 \pm 8.9$ & \multirow[t]{2}{*}{$P=0.001$} & 0.00 & 30.14 & $0(0 \%)$ \\
\hline & & Carrot & $33.13 \pm 9.6$ & & 15.11 & 56.99 & $0(0 \%)$ \\
\hline & \multirow[t]{2}{*}{ Autumn } & Watermelon & $18.65 \pm 23.17$ & \multirow[t]{2}{*}{$P=0.796$} & 2.24 & 73.82 & $0(0 \%)$ \\
\hline & & Carrot & $16.44 \pm 20.63$ & & 0.81 & 52.28 & $0(0 \%)$ \\
\hline & \multirow[t]{2}{*}{ Winter } & Watermelon & $20.62 \pm 20.41$ & \multirow[t]{2}{*}{$\mathrm{P}=0.038$} & 0.00 & 74.43 & $0(0 \%)$ \\
\hline & & Carrot & $33.29 \pm 8.4$ & & 24.58 & 54.87 & $0(0 \%)$ \\
\hline \multirow{8}{*}{ Cadmium } & \multirow{2}{*}{ Spring } & Watermelon & $1.31 \pm 0.76$ & \multirow{2}{*}{$\mathrm{P}=0.000$} & 0.00 & 2.99 & $0(0 \%)$ \\
\hline & & Carrot & $4.71 \pm 1.48$ & & 2.2 & 7.11 & $0(0 \%)$ \\
\hline & \multirow[t]{2}{*}{ Summer } & Watermelon & $1.23 \pm 0.54$ & \multirow[t]{2}{*}{$\mathrm{P}=0.000$} & 0.53 & 4.64 & $0(0 \%)$ \\
\hline & & Carrot & $4.45 \pm 1.72$ & & 1.75 & 7.30 & $0(0 \%)$ \\
\hline & \multirow[t]{2}{*}{ Autumn } & Watermelon & $3.23 \pm 2.19$ & \multirow[t]{2}{*}{$\mathrm{P}=0.155$} & 0.7 & 7.24 & $0(0 \%)$ \\
\hline & & Carrot & $6.1 \pm 6.24$ & & 2.24 & 26.20 & $0(0 \%)$ \\
\hline & \multirow[t]{2}{*}{ Winter } & Watermelon & $3.84 \pm 4.39$ & \multirow[t]{2}{*}{$\mathrm{P}=0.134$} & 0.69 & 13.40 & $0(0 \%)$ \\
\hline & & Carrot & $5.84 \pm 2.15$ & & 2.35 & 10.59 & $0(0 \%)$ \\
\hline \multirow[t]{8}{*}{ Nitrate } & \multirow[t]{2}{*}{ Spring } & Watermelon & $50870 \pm 31680$ & \multirow[t]{2}{*}{$\mathrm{P}=0.036$} & 15100 & 117950 & $3(25 \%)$ \\
\hline & & Carrot & $28680 \pm 19930$ & & 8630 & 78720 & $0(0 \%)$ \\
\hline & \multirow[t]{2}{*}{ Summer } & Watermelon & $33100 \pm 18100$ & \multirow[t]{2}{*}{$\mathrm{P}=0.008$} & 0.00 & 75830 & $0(0 \%)$ \\
\hline & & Carrot & $221930 \pm 226270$ & & 11860 & 599590 & $5(33.33 \%)$ \\
\hline & \multirow{2}{*}{ Autumn } & Watermelon & $39100 \pm 25100$ & \multirow[t]{2}{*}{$\mathrm{P}=0.000$} & 8430 & 75830 & $4(30 \%)$ \\
\hline & & Carrot & $299300 \pm 123010$ & & 181170 & 580340 & $8(53.53 \%)$ \\
\hline & \multirow[t]{2}{*}{ Winter } & Watermelon & $62290 \pm 54670$ & \multirow[t]{2}{*}{$P=0.029$} & 0.00 & 181170 & $5(41.66 \%)$ \\
\hline & & Carrot & $182990 \pm 173520$ & & 15100 & 510080 & $5(33 \%)$ \\
\hline
\end{tabular}

$\mathrm{PL}=$ Permissible level set by the Iranian Institute of Standards and Industrial Research $(\mu \mathrm{g} / \mathrm{kg})$. 
Table 4. Estimated exposure of the consumers to lead, cadmium and nitrate from watermelons and carrots.

\begin{tabular}{|c|c|c|c|c|c|c|c|c|c|c|c|c|}
\hline \multirow[b]{2}{*}{ Season } & \multirow[b]{2}{*}{ Food } & \multicolumn{4}{|c|}{ Lead } & \multicolumn{4}{|c|}{ Cadmium } & \multicolumn{3}{|c|}{ Nitrate } \\
\hline & & $\begin{array}{c}\text { ADD1 }^{1} \\
\text { (mg/kg } \\
\text { bw/day)1 }\end{array}$ & $\begin{array}{c}\text { WCS }^{2} \\
\text { (mg/kg } \\
\text { bw/day) }\end{array}$ & THQ $^{3}$ & ELCR $^{4}$ & $\begin{array}{c}\text { ADD } \\
\text { (mg/kg } \\
\text { bw/day) }{ }^{1}\end{array}$ & $\begin{array}{c}\text { WCC } \\
\text { (mg/kg } \\
\text { bw/day) }\end{array}$ & THQ & ELCR & $\begin{array}{c}\text { ADD } \\
\text { (mg/kg } \\
\text { bw/day) }{ }^{1}\end{array}$ & $\begin{array}{c}\text { WCC } \\
\text { (mg/kg } \\
\text { bw/day) }{ }^{2}\end{array}$ & THQ \\
\hline \multirow{3}{*}{ Spring } & Watermelon & $2.41 \mathrm{E}-05$ & $3.95 \mathrm{E}-05$ & 0.0688 & $2 \mathrm{E}-07$ & $1.9 \mathrm{E}-06$ & $4.4 \mathrm{E}-06$ & 0.0019 & $1.19 \mathrm{E}-05$ & 0.0759 & 0.1761 & 0.0474 \\
\hline & Carrot & $2.16 \mathrm{E}-05$ & $4.1 \mathrm{E}-05$ & 0.0617 & $1 \mathrm{E}-07$ & $2.5 \mathrm{E}-06$ & $3.7 \mathrm{E}-06$ & 0.0025 & $1.57 \mathrm{E}-05$ & 0.0153 & 0.0420 & 0.0095 \\
\hline & Watermelon & 2.87E-05 & $4.5 \mathrm{E}-05$ & 0.082 & $2 \mathrm{E}-07$ & $1.8 \mathrm{E}-06$ & $6.9 \mathrm{E}-06$ & 0.0018 & $1.13 \mathrm{E}-05$ & 0.0494 & 0.1132 & 0.0308 \\
\hline \multirow[t]{2}{*}{ Summer } & Carrot & $1.76 \mathrm{E}-05$ & $3.04 \mathrm{E}-05$ & 0.0502 & $1 \mathrm{E}-07$ & $6.6 \mathrm{E}-06$ & $3.9 \mathrm{E}-06$ & 0.0066 & $4.15 \mathrm{E}-05$ & 0.1185 & 0.3203 & 0.0740 \\
\hline & Watermelon & $2.78 \mathrm{E}-05$ & $1.102 \mathrm{E}-04$ & 0.0794 & $2 \mathrm{E}-07$ & $4.8 \mathrm{E}-06$ & $1.08 \mathrm{E}-05$ & 0.0048 & $3.02 \mathrm{E}-05$ & 0.0583 & 0.1360 & 0.0364 \\
\hline \multirow[t]{2}{*}{ Autumn } & Carrot & 8.7E-06 & $2.79 \mathrm{E}-05$ & 0.0248 & $7 \mathrm{E}-08$ & $3.2 \mathrm{E}-06$ & $1.39 \mathrm{E}-05$ & 0.0032 & $2.01 \mathrm{E}-05$ & 0.1599 & 0.3100 & 0.0999 \\
\hline & Watermelon & $3.07 \mathrm{E}-05$ & 1.111E-04 & 0.0877 & $2 \mathrm{E}-07$ & 5.7E-06 & $2 \mathrm{E}-05$ & 0.0057 & $3.59 \mathrm{E}-05$ & 0.0930 & 0.2705 & 0.0581 \\
\hline Winter & Carrot & $1.77 \mathrm{E}-05$ & $2.93 \mathrm{E}-05$ & 0.0505 & $2 \mathrm{E}-07$ & $3.1 \mathrm{E}-06$ & $5.6 \mathrm{E}-06$ & 0.0056 & $1.95 \mathrm{E}-05$ & 0.0977 & 0.2775 & 0.0610 \\
\hline Total & & $1.77 \mathrm{E}-4$ & 4.344E-4 & 0.5051 & 1.27 E-05 & $2.96 \mathrm{E}-5$ & $6.92 \mathrm{E}-5$ & 0.0321 & $\begin{array}{c}1.861 \mathrm{E}- \\
04\end{array}$ & 0.668 & 1.646 & 0.4171 \\
\hline
\end{tabular}

1; ADD; average daily dose; 2; WCS; worst case scenario; 3; THQ; target hazard quotient; 4; ELCR; excess lifetime cancer risk

\section{RESULTS}

Table 1 shows that carrot samples had the highest concentrations of $\mathrm{Pb}, \mathrm{Cd}$, and nitrate compared to those for watermelons $(\mathrm{p}<0.001)$. The mean concentrations of $\mathrm{Pb}$ and $\mathrm{Cd}$ were lower than the permissible limits required by Codex and ISIRI $(\mathrm{p}<0.001)$. The mean concentrations of nitrate in watermelon $(p=0.011)$ and carrot $(p=0.006)$ samples were also lower than the permissible limits. However, 12 (25\%) and 18 (30\%) of watermelon and carrot samples, respectively, had higher nitrate contents than the permissible limits. Compared to the limits, the percentages of $\mathrm{Pb}, \mathrm{Cd}$, and nitrate for watermelons were 18.68\%, 30.83\% and $4.8 \%$, while those for the carrot samples were $10.5 \%$, $77.17 \%$, and $73.3 \%$, respectively.

Lead Contents: The concentrations of $\mathrm{Pb}, \mathrm{Cd}$ and nitrate in decreasing order in the collected fruit and vegetable samples are shown in Table 2 . For $\mathrm{Pb}$, the seasonal order was: spring $>$ winter $>$ summer $>$ fall. The mean concentration for $\mathrm{Pb}$ content in watermelons was higher in the winter than in other seasons ( $p>0.05)$. The $\mathrm{Pb}$ content for carrots was lower in the fall than in other seasons $(p=0.001)$, with the highest content found in the spring.

Cadmium Contents: The order of Cd contents in the fruit and vegetable samples was: winter $>$ fall $>$ spring $>$ summer. The mean contents of $\mathrm{Cd}$ for watermelons was higher in the winter than in the spring $(\mathrm{P}<0.016)$ but the difference was not significant compared to those for other seasons. The mean Cd concentration for carrots was higher in the fall than in other seasons, but the differences were not significant compared to the data for other seasons.

Nitrate Contents: The order of nitrate contents in the fruit and vegetable samples was: fall > summer > winter $>$ spring. The nitrate concentration was higher in watermelon and carrot samples in the winter and autumn, while in the summer and spring we found the lowest concentrations for this compound. Based on our results, the highest number of samples with nitrate contents exceeded the ISIRI limit for watermelons and carrots. The percentages of the samples exceeding the limit in the winter and fall were $41.66 \%$ and $53.53 \%$, respectively.

Overall Contents: The order for the presence of all compounds in carrot samples were nitrate $>\mathrm{Pb}>\mathrm{Cd}$ (Table 3), unlike those for watermelon, in which the order was $\mathrm{Cd}>\mathrm{Pb}>$ nitrate. The exposure estimation, THQ and ECLR of $\mathrm{Pb}, \mathrm{Cd}$ and nitrate intakes from watermelons and carrots in the Iranian community are shown in Table 4. The results of THQ and total THQ for the compounds were in a range $(<1)$, that were not at hazardous levels (Fig. 1). However, the ELCR value for $\mathrm{Pb}$ was safe unlike that for $\mathrm{Cd}$.

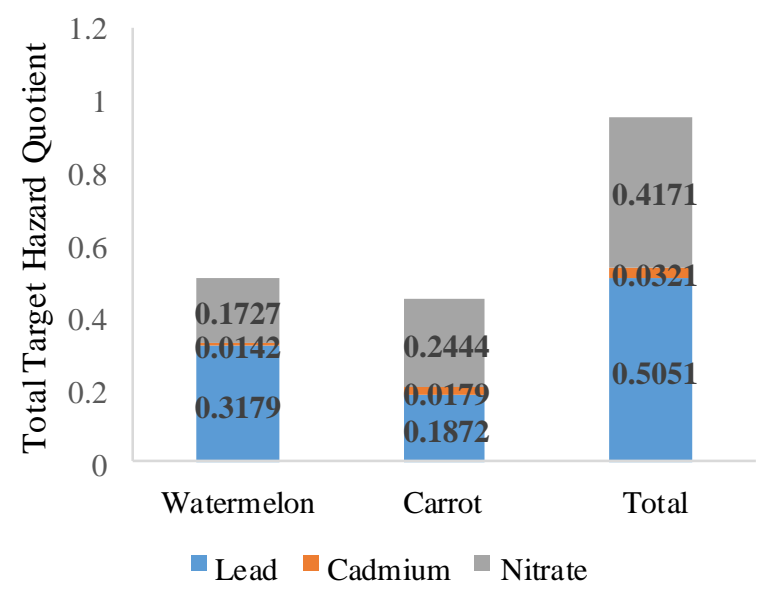

Figure 1. The comparison of the total target hazard quotient for lead, cadmium and nitrate in watermelon and carrot samples.

\section{DISCUSSION}

Lead Contents: As a non-essential heavy metal, lead can cause adverse health effects in humans, such as toxic conditions in the nervous and renal systems (17). Alimohammadiet al. reported the $\mathrm{Pb}$ content in fruits and vegetables from Tehran to be higher than the permissible limits (1). The $\mathrm{Pb}$ content in similar vegetables in Chinese markets was within the limit of the national standard $(\underline{18,19})$. A previous study reported that high concentrations of heavy metals in various parts of the vegetables might be related to the concentration in the polluted air due to industrial activities (20). This study showed that atmospheric depositions and marketing systems of vegetables play significant roles in elevating the levels of heavy metals

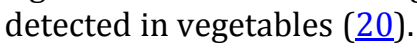

Cadmium Contents: As a highly toxic heavy metal, cadmium can cause severe toxicity to humans at low concentrations of about $1 \mathrm{mg} / \mathrm{kg}$ body weight (17). Several studies have shown that $\mathrm{Cd}$ concentration in popular vegetables, crops and fruits to range from 0.116 to $0.151 \mathrm{mg} / \mathrm{kg}$ in Tehran (1), 0.92 to $4.13 \mathrm{mg} / \mathrm{kg}$ 


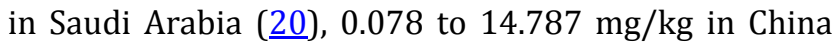
(18) and 0.24 to $10.96 \mathrm{mg} / \mathrm{kg}$ in Tabriz, Iran (21). Our results indicated that the $\mathrm{Cd}$ content in fruits ranged from below limit of detection to $0.026 \mathrm{mg} / \mathrm{kg}$. In agreement with our results, a previous study (1) reported that the $\mathrm{Cd}$ concentrations in similar fruits and vegetables from Tehran were lower than the permissible Iranian limits ( $\underline{1})$. Chen et al. (18) demonstrated that the transfer factors from soils to vegetables were dependent on the vegetable species. Leguminous vegetables were more likely to accumulate chromium, while leafy vegetables tended to show higher levels of $\mathrm{Cd}$ and $\mathrm{Pb}$. Melons demonstrated a relatively low capacity for accumulating the heavy metals. The transfer factors were positively correlated with the soil organic matter and negatively with the $\mathrm{pH}$ (18).

Nitrate Contents: Studies have reported that the nitrate concentrations in white and red onions, watermelons, spinach and tomatoes from Hamedan

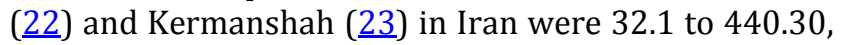
5.51 to $21.1,132.4$ to 413.4 and 3.002 to $17.07 \mathrm{mg} / \mathrm{kg}$, respectively. In contrast, the nitrate contents in watermelons from Kermanshah (a western Iranian city) were lower than that found in our study. The differences in the reported concentrations are likely to be related to the sampling locations and season of collecting fruits and vegetables. Brkić et al. (11) reported that nitrate concentrations in the spring samples were in the range of $436 \mathrm{mg} / \mathrm{kg}$ for chard to $1208.6 \mathrm{mg} / \mathrm{kg}$ for kale. For the fall season, the ranges were $248.46 \mathrm{mg} / \mathrm{kg}$ for chard to $2120.6 \mathrm{mg} / \mathrm{kg}$ for spinach in Croatia. Their results showed that there were higher concentrations of nitrate $(p<0.05)$ for spinach and kale samples detected in autumn than in the spring (11). Pourmoghim et al. showed that the nitrate contents in tomato and potato samples in the winter were higher than those in the summer (24). The results of the present study were consistent with the report of Pourmoghim et al. The differences in the reported data may be due to the fact that fruits sold in Kashan supermarkets may have come from different Iranian cities during the seasons evaluated by the current study. The accumulation of heavy metals in fruits and vegetables can be due to multiple factors, including soil characteristics and using untreated wastewaters and/or industrial fertilizers ( $\underline{1})$.

Regulatory Limits: Based on the Joint FAO and WHO Expert Committee on Food Additives (JECFA), provisional tolerable daily intakes (PTDI) for $\mathrm{Pb}$ and $\mathrm{Cd}$ are 0.0036 and $0.001 \mathrm{mg} / \mathrm{kg} \mathrm{bw/day,} \mathrm{respectively.}$ Interestingly, our results showed the ADD values for $\mathrm{Pb}$ and $\mathrm{Cd}$ contents in watermelon and carrot samples were less than those set by PTDI. Also, in the worst case scenario, the $\mathrm{Pb}(0.434 \mu \mathrm{g} / \mathrm{kg}$ bw/day) and $\mathrm{Cd}$ $(0.069 \mu \mathrm{g} / \mathrm{kg} \mathrm{bw} /$ day $)$ contents per day for all fruit samples were much lower than those set by PTDI. This suggests that the risks of adverse effects due to $\mathrm{Pb}$ and $\mathrm{Cd}$ contaminations in these fruits were negligible. Based on the JECFA guidelines, the acceptable daily intake (ADI) for nitrate is from zero to $3.7 \mathrm{mg} / \mathrm{kg}$ bw. In this study, the ADD levels of nitrate per day for watermelons and carrots in various seasons were lower than the ADI levels. In addition, the worst case condition of nitrate per day for all fruits $(1.67 \mathrm{mg} / \mathrm{kg}$ bw) was lower than the ADI limit. Therefore, our results demonstrated that the safety concerns regarding nitrate was negligible. The THQ values for the compounds studies in this study were in the safe range $(<1)$ for watermelon and carrot samples. Also, the TTHQ values were less than one (Table 3 and Fig. 1) and did not pose harmful effects to humans.

Cancer Risks: The excess lifetime cancer risk (ELCR) order for the two heavy metals was $\mathrm{Cd}>\mathrm{Pb}$. Our results conservatively suggest that the cancer producing risk of $\mathrm{Pb}$ was in the safe level based on the USEPA limits $\left(10^{-4}\right.$ to $\left.10^{-6}\right)$. In the case of Cd, the ELCR was higher $\left(1.861 \times 10^{-4}\right)$ than the range advised by USEPA. Our result for the total cancer risk was higher $\left(1.988 \times 10^{-4}\right)$ than the standard, hence at an unsafe level for the Iranian consumers. The results of ELCR for $\mathrm{Pb}$ and $\mathrm{Cd}$ that were adjusted for their bioavailability values, according to the USEPA guidelines, were still at unsafe levels. Consistent with our results, Alimohammadi et al. (1) reported that the evaluated HQ of the heavy metals were in the safe range $(<1)$ for the vegetables, and the TTHQ was less than 1 (0.63). Also, the ELCR order for the three heavy metals was $\mathrm{Cd}>\mathrm{As}>\mathrm{Pb}(\underline{1})$. Zhou et al. reported that the TTHQ values for $\mathrm{Pb}, \mathrm{Ni}, \mathrm{Cd}$ and $\mathrm{As}$ were more than 1 in Shizhuyuan area of China, suggesting that the residents may be facing potential health risks due to the vegetable consumptions (19). Salehipour et al. demonstrated that the health risk contributed by $\mathrm{Ni}$ was minimal, compared to those for other metals (25). Also the total non-carcinogenic hazard of $\mathrm{As}$ and $\mathrm{Pb}$ were more than 1 , and the total cancer risk of As was slightly greater than $10^{-4}$ for the vegetables produced in Isfahan province $(\underline{25})$.

Regulations: In recent years, regulatory organizations have become aware of the harmful effects and the considerable health risks posed by heavy metals. Therefore, they have begun to accurately monitor the heavy metal levels in various foods, and apply good agricultural practices, such as using correct amount of industrial fertilizers and treated wastewater. These steps are warranted to reduce heavy metal contaminations in agricultural products and to

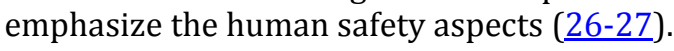

\section{CONCLUSIONS}

This study evaluated the $\mathrm{Pb}, \mathrm{Cd}$ and nitrate concentrations in watermelon and carrot samples in Kashan, and estimated the daily intakes and the health risks to the population due to the consumption of fruits and vegetables. The results demonstrated that all of the samples except for some, contained $\mathrm{Pb}, \mathrm{Cd}$, and nitrate, although at less than the limits set by the regulatory organizations in Iran. High concentrations of $\mathrm{Pb}$ and $\mathrm{Cd}$ were detected in local fruits in all seasons except for the summer. The nitrate contamination was highest in the fall and lowest in the spring. The results indicated that the THQ and TTHQ values for the tested compounds were in the safe range $(<1)$ for watermelon 
and carrot samples, hence they were not present at harmful levels to human consumers. The ELCR values for $\mathrm{Pb}$ was safe but not for $\mathrm{Cd}$. The ELCR value for $\mathrm{Cd}$ was more than that recommended range by USEPA. Lastly, the total cancer risks were higher than the standard limits, hence at unsafe limits for the consumers in Kashan province.

\section{ACKNOWLEDGMENTS}

Authors are thankful to the Research Department of Kashan University of Medical Sciences, Kashan, Iran, for the financial support provided to this study.

\section{CONFLICTS OF INTERESTS}

The authors declare that there were no conflicts of interest in conducting this study.

\section{REFERENCES}

1. Alimohammadi M, Younesian M, Madihi-Bidgoli S, et al. Heavy metal(oid)s concentration in Tehran supermarket vegetables: carcinogenic and non-carcinogenic health risk assessment. Toxin Reviews. 2018; 1-8. Doi.org/10.1080/15569543.2018.

2. Baharom ZS, Ishak MY. Determination of heavy metal accumulation in fish species in Galas River, Kelantan and Beranang mining pool, Selangor. Procedia Environmental Sciences. 2015;30:320-325.

3. Corguinha APB, de Souza GA, Gonçalves VC, et al. Assessing arsenic, cadmium, and lead contents in major crops in Brazil for food safety purposes. Journal of Food Composition and Analysis. 2015; 37: 143-150.

4. Sharafati Chaleshtori F, Rafieian Kopaei M, Sharafati Chaleshtori R. A review of heavy metals in rice (Oryza sativa) of Iran. Toxin Reviews. 2017;36(2):147-153.

5. Luo C, Liu C, Wang Y, et al. Heavy metal contamination in soils and vegetables near an e-waste processing site, south China. Journal of hazardous materials. 2011;186(1):481-490.

6. Bryan NS, Alexander DD, Coughlin JR, et al. Ingested nitrate and nitrite and stomach cancer risk: An updated review. Food and Chemical Toxicology. 2012;50(10):3646-3665.

7. Chetty AA, Prasad S, Pinho OC, et al. Estimated dietary intakes of nitrate and nitrite from meat consumed in Fiji. Food Chemistry. 2018;278:630-635.

8. Sindelar JJ, Milkowski AL. Human safety controversies surrounding nitrate and nitrite in the diet. Nitric oxide. 2012;26(4):259-266.

9. Santarelli RL, Pierre F, Corpet DE. Processed meat and colorectal cancer: a review of epidemiologic and experimental evidence. Nutrition and cancer. 2008;60(2):131-144.

10. Bahadoran Z, Mirmiran P, Jeddi S, et al. Nitrate and nitrite content of vegetables, fruits, grains, legumes, dairy products, meats and processed meats. Journal of Food Composition and Analysis. 2016;51:93-105.

11. Brkić D, Bošnir J, Bevardi M, et al. Nitrate in Leafy Green Vegetables and Estimated Intake. African Journal of Traditional, Complementary and Alternative Medicines. 2017;14(3):31-41.

12. AOAC (Association of Official Analytical Chemists). Official Method of Analysis. Nitrites in Cured Meats-Colorimetric Method, Official AOAC Method, Arlington, VA, USA .2000; 973.
13. ISIRI (Institute of Standards and Industrial Research of Iran). Fruits and vegetables-Onion: Measuring of nitrate and nitrite - Spectrophotometric method. NO 7132. Amendment No.1, 2014.

14. ISIRI (Institute of Standards and Industrial Research of Iran). Food \& Feed-Maximum limit of heavy metals. NO 12967, 1st edition, 2010 http://standard.isiri.gov.ir/StandardView.aspx?Id=3036.

15. USEPA (United States Environmental Protection Agency). Risk Assessment Guidance for Superfund Volume 1: Human Health Evaluation Manual (Part A); United States Environmental Protection Agency, Washington, DC, USA. $1989 . \quad$ Available at: https://www.epa.gov/sites/production/files/201509/documents/rags_a.pdf.

16. IRIS. IRIS-Integrated Risk Information System, U.S. EPA (2012) Nitrate (CASRN 14797-55-8). 2012. http://www.epa.gov/iris/subst/0076.htm. Environmental Science and Pollution Research.

17. Ullah AA, Maksud M, Khan S, Lutfa L, Quraishi SB. Dietary intake of heavy metals from eight highly consumed species of cultured fish and possible human health risk implications in Bangladesh. Toxicology Reports. 2017;4:574-579.

18. Chen $\mathrm{Y}, \mathrm{Wu} \mathrm{P}, \mathrm{Shao} \mathrm{Y}$, et al. Health risk assessment of heavy metals in vegetables grown around battery production area. Scientia Agricola. 2014;71(2):126-132.

19. Zhou H, Yang WT, Zhou X, et al. Accumulation of heavy metals in vegetable species planted in contaminated soils and the health risk assessment. Intl. J. of Environ. Res. Public Health. 2016;13(3):289. Doi:10.3390/ijerph13030289.

20. Ali MH, Al-Qahtani KM. Assessment of some heavy metals in vegetables, cereals and fruits in Saudi Arabian markets. The Egyptian Journal of Aquatic Research. 2012;38(1):31-37.

21. Taghipour H, Mosaferi M. Heavy metals in the vegetables collected from production sites. Health Promotion Perspectives. Doi:10.5681/hpp.2013.022.

2013;3(2):185-193

22. Mousavi Moayeid F, Cheraghi M, Lorestani B. Investigation of the Amount of Phosphate and Nitrate Accumulation in Consumable Onion in Hamedan City. Journal of Neshabur University of Medical Sciences. 2017;4(4):82-89.

23. Pirsaheb M, Sharafi K, Morad M. A survey on nitrite and nitrate levels in vegetables and cucurbits cultivated in northern and western plains of Kermanshah City in 2012. Food Hygiene. 2013;3(9):77-78.

24. Pourmoghim M, Khoshtinat $\mathrm{K}$, Sadeghi makkei A, et al. Determination of nitrate contents of lettuce, tomatoes and potatoes on sale in Tehran central fruit and vegetable market by HPLC. Iranian Journal of Nutrition Sciences \& Food Technology. 2010;5(1):63-70.

25. Salehipour M, Ghorbani H, Kheirabadi $H$, et al. Health risks from heavy metals via consumption of cereals and vegetables in Isfahan Province, Iran. Human and Ecological Risk Assessment. 2015; 21(7):1920-1935.

26. Chaleshtori RS, Salehi E. Ochratoxin A in food products in Iran: A systematic review of the evidence. International Archives of Health Sciences. 2018;5(2):25-32.

27. Chaleshtori FS, Arian A, Chaleshtori RS. Assessment of sodium benzoate and potassium sorbate preservatives in some products in Kashan, Iran, with estimation of human health risk. Food and Chemical Toxicology. 2018;120:634-638. 